\title{
Prolactin and Luteinizing Hormone Cells of Pregnant and Lactating Rats as Studied by Immunohistochemistry and Radioimmunoassay '
}

\author{
FREDERICK W. MERCHANT ${ }^{2}$ \\ Department of Anatomy, The University of Michigan Medical School, \\ Ann Arbor, Michigan 48104
}

\begin{abstract}
The objective was to describe the cytological changes that occur in prolactin and luteinizing hormone (LH) cells of the rat hypophysis during pregnancy and lactation and to correlate these changes with secretory activity of the two cell types. The cells were demonstrated with immunohistochemistry and secretory activity was indicated by pituitary and serum hormone concentrations as measured by radioimmunoassay.

During pregnancy, two forms of prolactin cells were observed in the pars distalis. One form (prolactin cell I) was small, polyhedral, and constituted most of the prolactin cell population. A second form (prolactin cell II) was found occasionally in pituitary glands of nonpregnant rats and became prominent during pregnancy. It was polyhedral, many times larger than prolactin cell I, and had a restricted distribution in the pars distalis. During gestation prolactin cells I exhibited little change in size, number and staining capacity. Similarly, pituitary and serum prolactin concentrations indicated that the hypophysis releases little prolactin during pregnancy, except for the first few days after conception and before parturition. During lactation, the staining intensity of prolactin cells $I$ and the pituitary prolactin concentration varied little. Prolactin cells II were lightly stained and rare throughout lactation.

The staining capacity of luteinizing hormone ( $\mathrm{LH}-$ ) cells increased as pregnancy progressed in parallel with a rising pituitary concentration of $\mathrm{LH}$ during the first half of pregnancy. However, the immunohistochemical procedure appeared to be too insensitive to reflect the gradual fall in pituitary LH concentration during late pregnancy. During early lactation, the reduced staining capacity of LH-cells was correlated with a low pituitary concentration.
\end{abstract}

Cytological modifications that may occur in the hypophyseal pars distalis during pregnancy and lactation are poorly understood. There is some evidence that during pregnancy in the rat cytological changes occur in acidophils that suggest accelerated secretory activity. Although Haterius ('32), Stein ('34), and Desclin ('34) were unable to demonstrate significant variation in the percentage of acidophils, Wolfe and Cleveland (' 33 ) observed that during the latter two-thirds of pregnancy acidophils (their type I cell) hypertrophy. Severinghaus ('39) reported that many acidophils have an enlarged Golgi apparatus and abundant mitochondria during pregnancy and postulated that such alterations suggest accelerated secretory activity. Similarly, Lacour ('50) and Pasteels ('63), using differential staining techniques, observed hypertrcphy of a subgroup of acidophils that they believed to be the source of prolactin.

With respect to the influence of pregnancy on the basophil class of cells, Wolfe and Cleveland ('33) reported that they enlarge and increase in number during the

1 This investigation was supported, in part, by NIH Anatomical Science Training grant GM-312 and NIH research grant HD-03159.

2 Present address: Department of Biological Structure, School of Medicine, University of Washington, Seattle, Washington 98195. 
latter two-thirds of pregnancy in the rat; similarly Pasteels ('63) concluded that $\gamma$-cells (a subgroup of basophils) multiply early in pregnancy and accumulate glycoprotein as gestation progresses. Pasteels regarded $\gamma$-cells as the source of luteinizing hormone. Additional study is needed to determine which type of cell(s) in the basophil class changes during pregnancy.

In hypophyses of lactating rats, Everett and Baker ('45) reported on the basis of differential cell counts that at three to seven days postpartum the relative percentage of acidophils increases almost $100 \%$. No distinction was made between the acidophils that produce growth hormone and those that secrete prolactin. Later Pasteels ('63) described a similar response in erythrosinophils (a subgroup of acidophils believed to secrete prolactin), which was accompanied by cellular hypertrophy that peaked at six days. Since these changes seemed to parallel the rise and fall of pituitary prolactin content as determined by Meites and Turner ('48) with bioassay, it was deduced that acidophils are the source of prolactin. As for basophils, Stein ('34) and Everett and Baker ('45) found no changes during lactation while Pasteels ('63) reported that $\gamma$-cells "involute" early and remain unaltered during the remainder of lactation; $\beta$ basophils were said to be unmodified.

It is clear that the issue of cytological change in the pars distalis during pregnancy and lactation needs to be re-examined with a more specific method for identification of cell types. Hence, two objectives were posed for this investigation. First, prolactin cells and LH-cells were analyzed during pregnancy and lactation by immunohistochemistry. Second, in order to make possible a functional interpretation of the structural changes observed, the concentrations of prolactin and luteinizing hormone in the hypophysis and blood were quantified by radioimmunoassay during pregnancy and lactation at the same times when the cytological examinations were made.

\section{MATERIALS AND METHODS}

Experimental animals. Mature female rats (Sprague-Dawley Co., Madison, Wisconsin) were maintained at $23^{\circ} \mathrm{C}$ with 14 hours of illumination daily and given water and Purina rat chow ad libitum. Females were placed with mature males on the

TABLE 1

Summary of distribution of animals for immunohistochemistry (IHC) and radioimmunoassay (RIA)

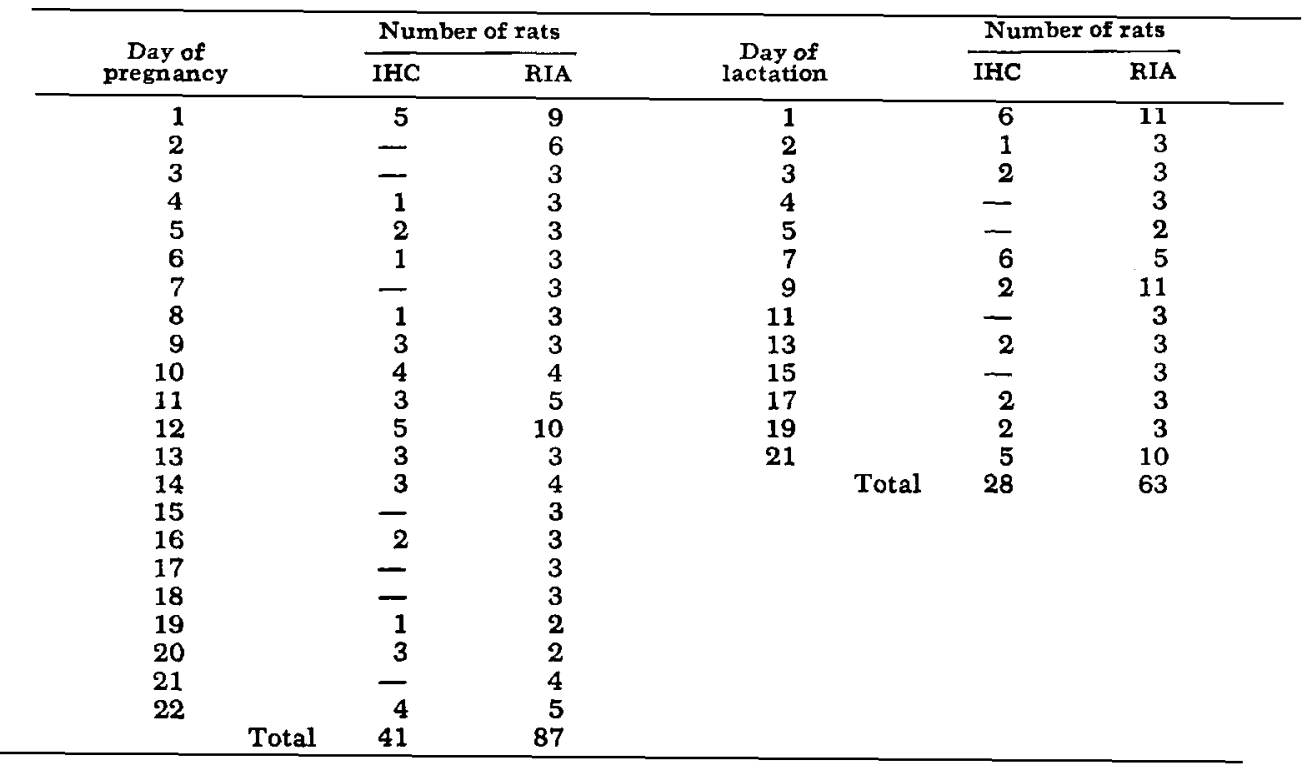


evening of proestrus, and mating was confirmed the next morning (day 1 of pregnancy) by the presence of spermatozoa in the vaginal smears. Animals were killed on each day of gestation and on days 1-5, $7,9,11,13,15,17,19$, and 21 of lactation (table 1 for distribution of animals). During lactation, size of the litter was maintained at six and the young were removed from each mother rat 18 hours before she was killed. In addition, several females were killed in proestrus after being observed to experience two successive estrous cycles. Their hypophyses served as a baseline for determination of cytological changes occurring during pregnancy and lactation. Vaginal smears were made on microscopic slides and stained so that the accuracy of staging could be checked. All animals were killed by decapitation between 0800 and 1100 hours.

Procurement of hypophyses and serum. Hypophyses to be stained were fixed in situ on Bouin's fluid for 24 hours, dehydrated, embedded in paraffin, and sectioned at 3 $\mu$ on a dorsoventral (transverse) plane. Representative sections from three different zones in the hypophysis were stained for study.

Pituitary glands to be assayed for hormone content were excised and, after separation from the pars nervosa, the pars distalis was weighed, homogenized, and diluted to a concentration of $1 \mathrm{mg} / \mathrm{ml}$ with $0.1 \%$ gelatin-phosphate-buffered saline (PBS). The homogenates were centrifuged at $8,000 \mathrm{rpm}$ for 30 minutes at $4^{\circ} \mathrm{C}$; the supernate was distributed into aliquots and frozen quickly in an ethanol-dry ice bath.

Individual blood samples obtained from all rats after decapitation were centrifuged at $2,400 \mathrm{rpm}$ for 30 minutes at $4^{\circ} \mathrm{C}$; the serum was distributed into aliquots and frozen quickly. All pituitary and serum samples were stored at $-20^{\circ} \mathrm{C}$ until assayed for luteinizing hormone and prolactin.

Immunohistochemical technique. Immunohistochemical staining was carried out according to the method of Nakane and Pierce ('67). 3,3'-Diaminobenzidine served as the substrate for the peroxidase reaction. Antisera to rat prolactin (antiprolactin $)^{3}$ and ovine luteinizing hormone
(anti-oLH) were from rabbits immunized according to the method of Midgley et al. ('71).

Several control procedures were carried out to verify the specificity of the staining reaction. No staining of prolactin or LHcells was obtained under the following conditions: substitution of normal rabbit serum for anti-prolactin or anti-oLH; incubation of tissue sections in peroxidase substrate without prior treatment with the appropriate antiserum or $\gamma$-globulin-peroxidase conjugate; or by blockade of immunoreactive sites on the hormone antibody when attached to the prolactin or LH-cell by application of unconjugated anti-rabbit- $r$ globulin prior to treatment with conjugated anti-rabbit- $\gamma$-globulin. No staining of LH-cells occurred if the antioLH had been absorbed previously with luteinizing hormone (NIH-LH-Bl). Earlier studies in this laboratory showed that the utility of anti-rat prolactin for immunohistochemical staining could be almost completely destroyed by absorption with purified rat prolactin. As further proof of specificity of the immunohistochemical procedure for prolactin and LH-cells, Baker et al. ('69) and Baker et al. ('72) showed that prolactin and LH-cells so revealed react in a predictable manner when activity of the cells and pituitary content of the hormone are altered by experimental means. Also, Baker et al. ('72) demonstrated that antiserum to the specific subunit of bLH- $\beta$ permits immunohistochemical staining of the same cells in the rat as anti-oLH and anti-human chorionic gonadotropin.

Radioimmunoassay. Serum and pituitary samples were assayed utilizing radioimmunoassay procedures as described previously for luteinizing hormone (Niswender et al., '68) and prolactin (Niswender et al., '69) with the exception that $0.1 \%$ gelatinPBS was used rather than PBS- $1 \%$ lyophilized egg-white. The amount of hormone was expressed in terms of a standard curve based on either a reference preparation of prolactin (NIAMD-Rat-Prolactin-RP-1) or luteinizing hormone (NIAMD-Rat-LH-RP-1) both being gifts of the National Institute of

\footnotetext{
3 The prefix "anti-" stands for antiserum to the hormone subsequently named. The small letter preceding the name of the hormone indicates the species of origin, e.g., "o" = ovine.
} 
Arthritis and Metabolic Diseases to Dr. A. R. Midgley, Jr.

Statistical methods. By utilizing computer programs developed to interpret radioimmunoassay data (Duddleson et al., '72), a weighted, least squares regression analysis was performed on all assay results. In addition, Student $t$ tests and analyses of variance were carried out on all radioimmunoassay results using the MIDAS (Michigan Interactive Data Analysis System) statistical computer programs developed at the University of Michigan (Fox and Guire, '72). A p value equal to or less than 0.05 was considered significant.

\section{OBSERVATIONS}

\section{Cytology of prolactin cells during pregnancy and lactation}

During pregnancy, two forms of prolactin cells could be observed in the rat hypophyseal pars distalis. One form was small and polyhedral; it constituted by far the greater proportion of the prolactin cell population in the pregnant and nonpregnant state. For descriptive purposes this form will be designated prolactin cell I (fig. 14). Also, during gestation a second form of prolactin cell that can be found occasionally in pituitary glands of nonpregnant rats became prominent. It was also polyhedral, but many times larger than prolactin cell I. It had a distinctive location within the gland, appearing in a region restricted to the lateral, central and caudal area of each lobe of the pars distalis (figs. 15, 16). This cell will be designated prolactin cell II.

Prolactin cells I and II differed somewhat in their response to pregnancy. During the first days of pregnancy prolactin cells I were large, had rather dispersed cytoplasmic granules (figs. 11, 12) and resembled prolactin cells of the proestrous female hypophysis (figs. 9, 10). During later periods it was difficult to ascertain whether any significant change had occurred because of variation between animals and between prolactin cells in different areas of a single section. In some rats, as illustrated by a specimen on day 14 (figs. 13, 14) prolactin cells I appeared smaller and more intensely stained due to compaction of the population of secretory granules as compared with those on the first day of pregnancy (figs. 11, 12). Such a change was not true of all specimens. On the other hand, prolactin cells II were unobtrusive during early pregnancy because of their weak staining and thus, only rarely could they be identified (fig. 12). By day 14, however, prolactin cells II became more evident due to their increased staining reaction (fig. 14). These cells continued to increase in staining capacity as pregnancy progressed so that by day 22 they were quite prominent (figs. 15, 16).

With respect to lactation, there was little change in staining capacity, size, or number of the prolactin cells I when compared to day 22 of pregnancy; however, prolactin cells II were rarely found after the first day of lactation (fig. 20). Thus, on day 1 of lactation (figs. 17, 18) the appearance of the prolactin cells I was similar to that on day 22 of pregnancy (figs. 15, 16) and for the remainder of lactation they showed little variation (fig. 20). The prolactin cells II, that were so deeply stained during late pregnancy, declined rapidly in staining capacity so that few such cells could be found on day 1 of lactation (figs. 17,18 ) and only an occasional, weakly stained cell was evident thereafter (figs. 19,20 ).

\section{Prolactin concentration in the hypophysis and serum during pregnancy and lactation}

During the first half of pregnancy, there was no significant variation in pituitary prolactin concentration; however, greater modulation in pituitary concentration was evident during the latter half of gestation. Thus, the average pituitary prolactin concentration between days 1 and 11 was $383.5 \pm 74.3 \mathrm{ng} / \mathrm{mg}$ (fig. 1) with none of the intervening day-to-day variations being significant. However, from days 12 to 16 , pituitary prolactin concentration gradually declined, reaching its lowest level on day 16 (157.8 $\pm 65.1 \mathrm{ng} / \mathrm{mg})$ $(\mathrm{p}<0.03)$. By day 18 an increase $(\mathrm{p}<0.03)$ had occurred in prolactin concentration over day 16 . However, by day 21 another decline had occurred $(p<0.03)$. The mean value for days $12-22$ was sig- 


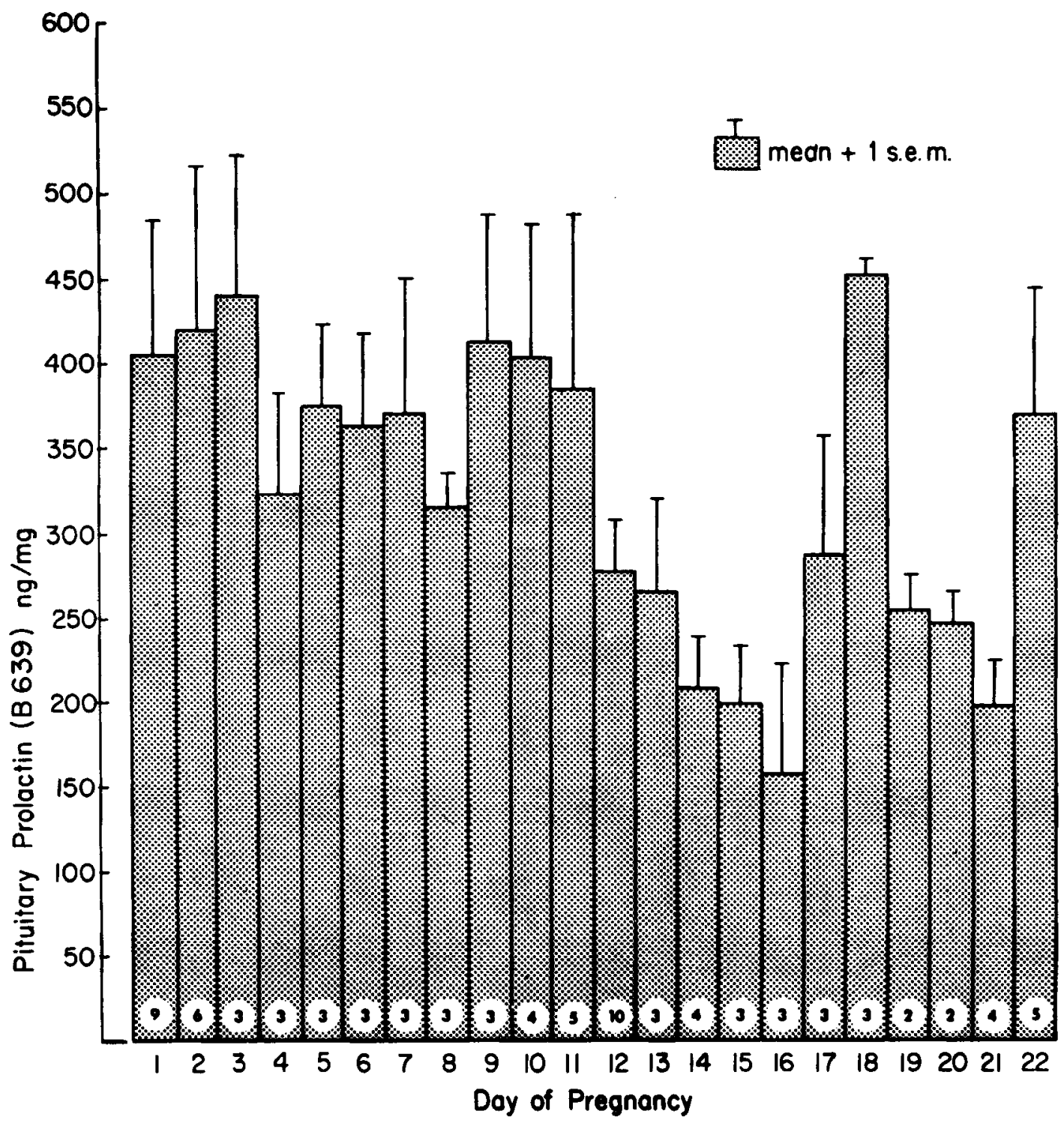

Fig. 1 Pituitary prolactin concentration at various times during pregnancy as determined by radioimmunoassay. B639 represents the standard reference preparation for prolactin (NLAMD-RatProlactin-RP-1). The number of rats used to obtain the specified mean concentrations is given at the bottom of each bar.

nificantly lower than the mean value for days 1-11 $(p<0.05)$.

As for lactation, pituitary prolactin concentration varied little except that a somewhat lower prolactin concentration was observed during the last few days. Thus, no significant change occurred in pituitary prolactin concentration from day 1 to 15 (average $420.2 \pm 57.2 \mathrm{ng} / \mathrm{mg}$ ) (fig. 2). By day 17 , however, a decrease $(p<0.03)$ in prolactin concentration below the level on day 15 was evident. This lowered concentration of prolactin was not altered significantly during the subsequent days of lactation.

Serum prolactin concentration was 


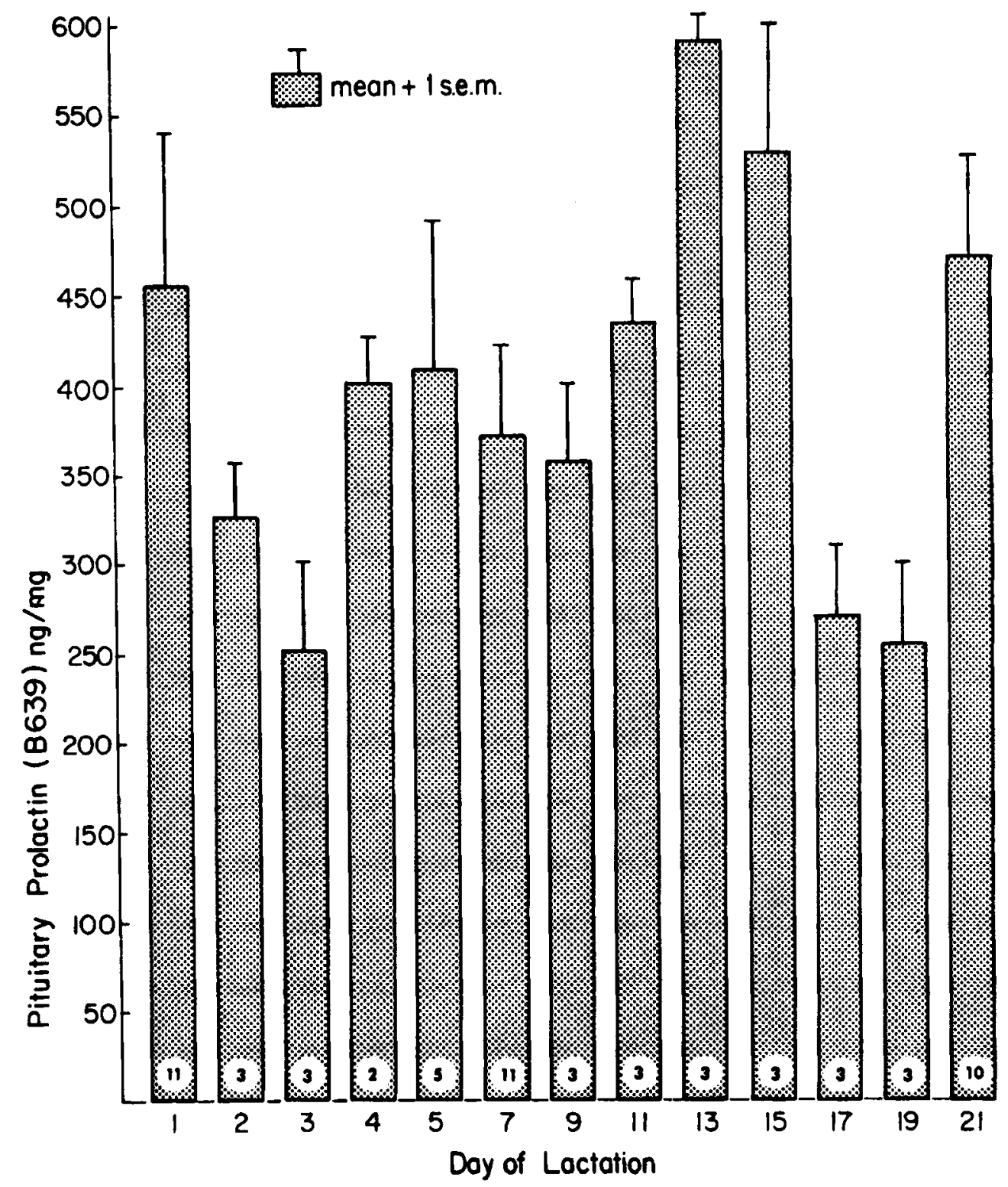

Fig. 2 Pituitary prolactin concentration at various times during lactation as determined by radioimmunoassay. B639 is the standard reference preparation. The number of rats used to obtain the specified mean concentrations is given at thebottom of each bar.

higher during early and late pregnancy than in the middle. Thus, for the first eight days the serum level (fig. 3 ) was highest on days $3(96.2 \pm 21.6 \mathrm{ng} / \mathrm{ml}), 7$ $(86.5 \pm 36.8 \mathrm{ng} / \mathrm{ml})$, and $8(82.5 \pm 18.7$ $\mathrm{ng} / \mathrm{ml}$ ). However, on day 9 serum prolactin had fallen abruptly $(p<0.005)$ to a mean concentration of $21.3 \pm 1.6 \mathrm{ng} / \mathrm{ml}$, this level remaining unchanged until day $22(93.5 \pm 29.6 \mathrm{ng} / \mathrm{ml})$ when the concentration was higher than on day 21 $(\mathrm{p}<0.002)$.

With respect to lactation, serum prolactin concentration gradually decreased 


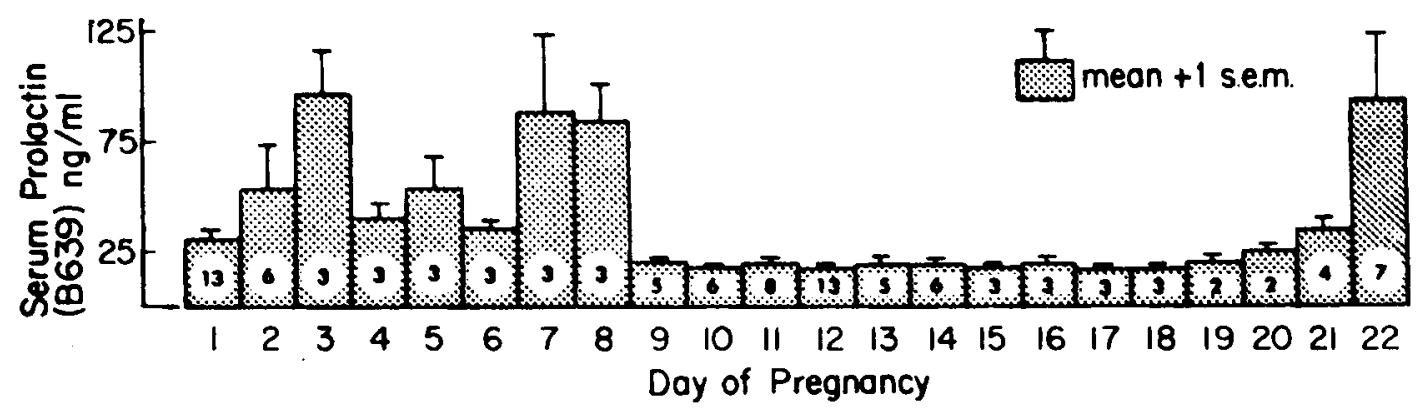

Fig. 3 Serum prolactin at various times during pregnancy as determined by radioim. munoassay. $\mathrm{B} 639$ is the standard reference preparation. The number of rats used to obtain the specified mean concentrations is given at the bottom of each bar.

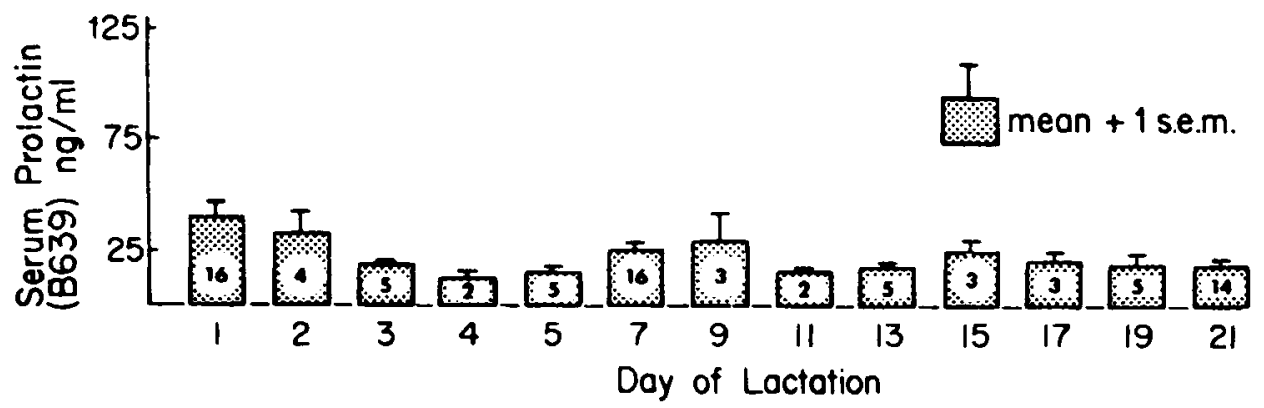

Fig. 4 Serum prolactin at various times during lactation as determined by radioimmuno. assay. B639 is the standard reference preparation. The number of rats used to obtain the specified mean concentrations is given at the bottom of each bar.

from day $1(41.2 \pm 7.1 \mathrm{ng} / \mathrm{ml})$ to day 3 $(18.8 \pm 0.7 \mathrm{ng} / \mathrm{ml})(\mathrm{p}<0.01)$ and continued unchanged during the subsequent postpartum period (days 4-21) (fig. 4).

\section{Cytology of the LH-cells during pregnancy and lactation}

LH-cells as observed by immunohistochemical staining revealed profound alterations during pregnancy. On day 1 (figs. 23, 24) LH-cells were small, lightly stained, and the number identifiable was decreased when compared to LH-cells in hypophyses of proestrous females (figs. 21, 22). The cytological picture observed on day 1 was maintained for approximately three to four days; however, by day 5 LH-cells began to increase in staining capacity and apparent number so that on day 12 (figs. 25, 26) LH-cells were much more prominent than on day 1 of pregnancy. As gestation progressed, LH-cells continued to increase in staining capacity and size so that by day 22 (figs. 27,28 ) a striking change had occurred in their status as compared with day 1 (figs. 23, 24).

As compared with late pregnancy, on day 1 of lactation a drastic decrease had occurred in staining capacity, size, and number of identifiable LH-cells (figs. 29, $30)$. This condition of the LH-cells was maintained for three to four days of lactation, but by day 5 their staining capacity had increased and their status then remained unchanged through day 21 of lactation (figs. 31, 32). The staining capacity of LH-cells on day 21 of lactation, however, did not equal that observed on day 22 of pregnancy.

\section{LH concentration in the hypophysis and serum during pregnancy and lactation}

Pituitary LH concentration during pregnancy (fig. 5) was lowest during the first four days (mean, $5.7 \pm 1.2 \mu \mathrm{g} / \mathrm{mg}$ ) but the level had risen $(p<0.008)$ by day 5 (15.3 $\pm 0.7 \mu \mathrm{g} / \mathrm{mg}$ ) and, thereafter, con- 


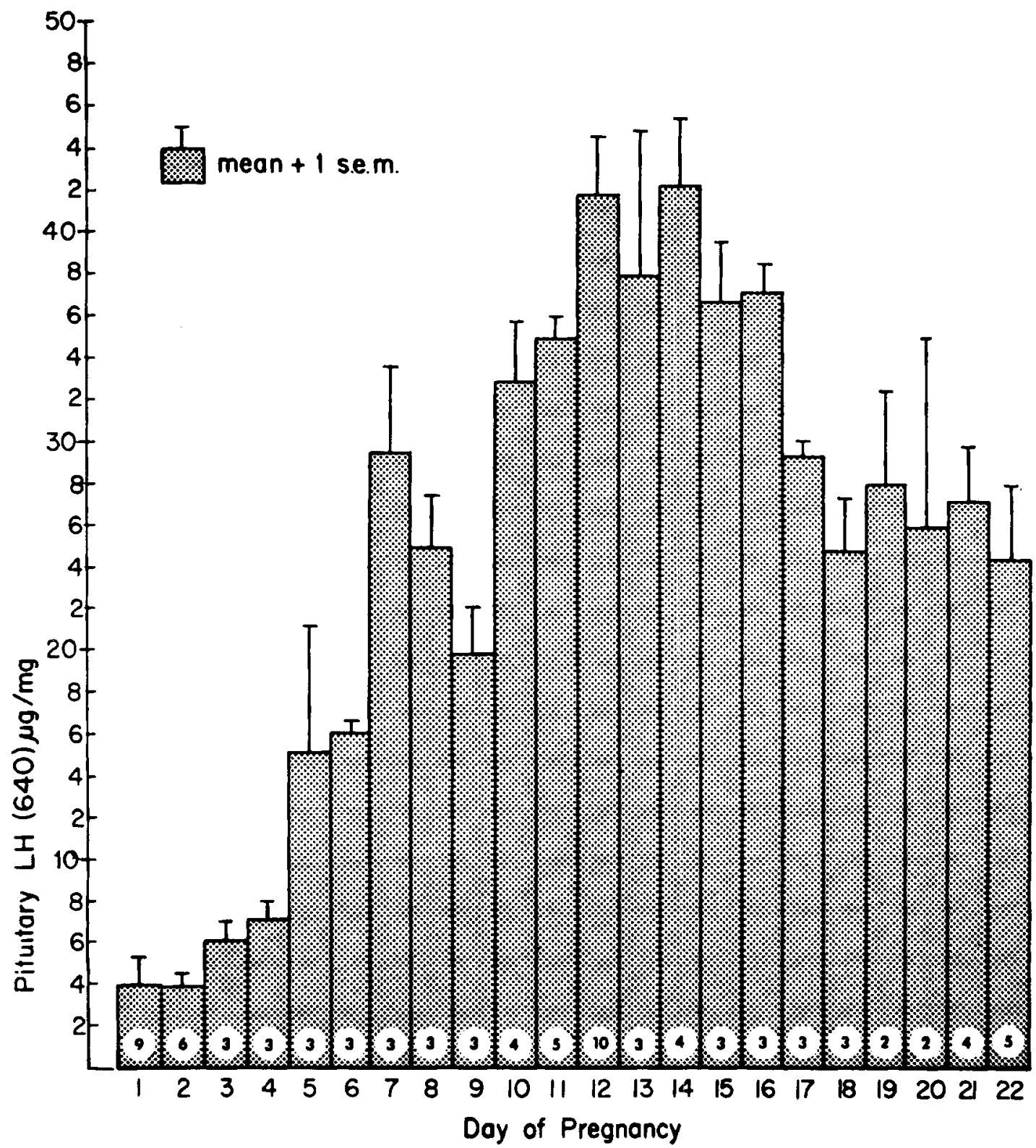

Fig. 5 Pituitary LH concentration at various times during pregnancy as determined by radioimmunoassay. B640 represents the standard reference preparation for LH (NIAMD-Rat-LH-RP-1). The number of rats used to obtain the specified mean concentration is given at the bottom of each bar.

tinued upward to a peak on day 14 $(42.6 \pm 3.3 \mu \mathrm{g} / \mathrm{mg}$ ). From day 14 to day 17 the $\mathrm{LH}$ concentration declined $(\mathrm{p}<0.007)$ to $29.5 \pm 0.7 \mu \mathrm{g} / \mathrm{mg}$ and underwent only insignificant variation dur- ing the remainder of pregnancy (days 18-22).

As for lactation, a marked reduction in pituitary LH concentration (fig. 6) occurred on day $1(2.1 \pm 0.4 \mu \mathrm{g} / \mathrm{mg})$ when 


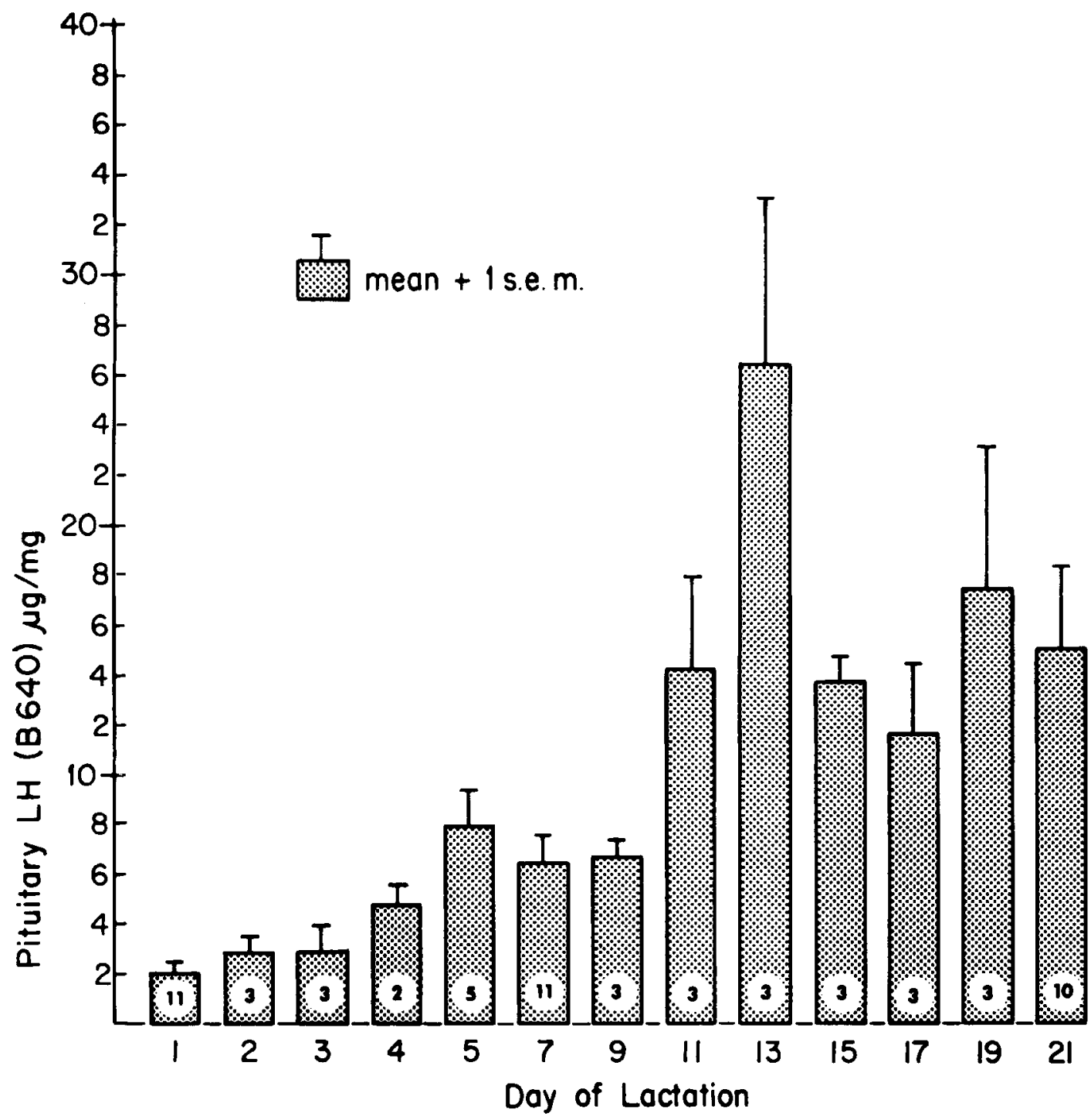

Fig. 6 Pituitary LH concentration at various times during lactation as determined by radioimmunoassay. B640 is the standard reference preparation. The number of rats used to obtain the specified mean concentrations is given at the bottom of each bar.

compared to the high mean concentration on day 22 of pregnancy. This low concentration was maintained for the first nine days of lactation $(p<0.24)$. On day 13 (26.5 $\pm 7.4 \mu \mathrm{g} / \mathrm{mg}$ ) a peak in luteinizing hormone concentration had been reached. Although the level of $\mathrm{LH}$ concentration on days $15-21$ (average, $15.1 \pm 2.6 \mu \mathrm{g} / \mathrm{mg}$ ) was lower than for day $13(p<0.01)$, it was still higher than during the first nine days.
Serum LH concentration during pregnancy (fig. 7) gradually decreased from day $1(22.0 \pm 4.4 \mathrm{ng} / \mathrm{ml})$ to day 15 $(1.8 \pm 1.1 \mathrm{ng} / \mathrm{ml})(\mathrm{p}<0.008)$. This low level remained unchanged through day 21 , but an abrupt increase $(p<0.008)$ occurred on day $22(25.5 \pm 5.5 \mathrm{ng} / \mathrm{ml})$. In general, the curve for serum $\mathrm{LH}$ concentration was roughly reciprocal to the curve for pituitary $\mathrm{LH}$ concentration during pregnancy. 


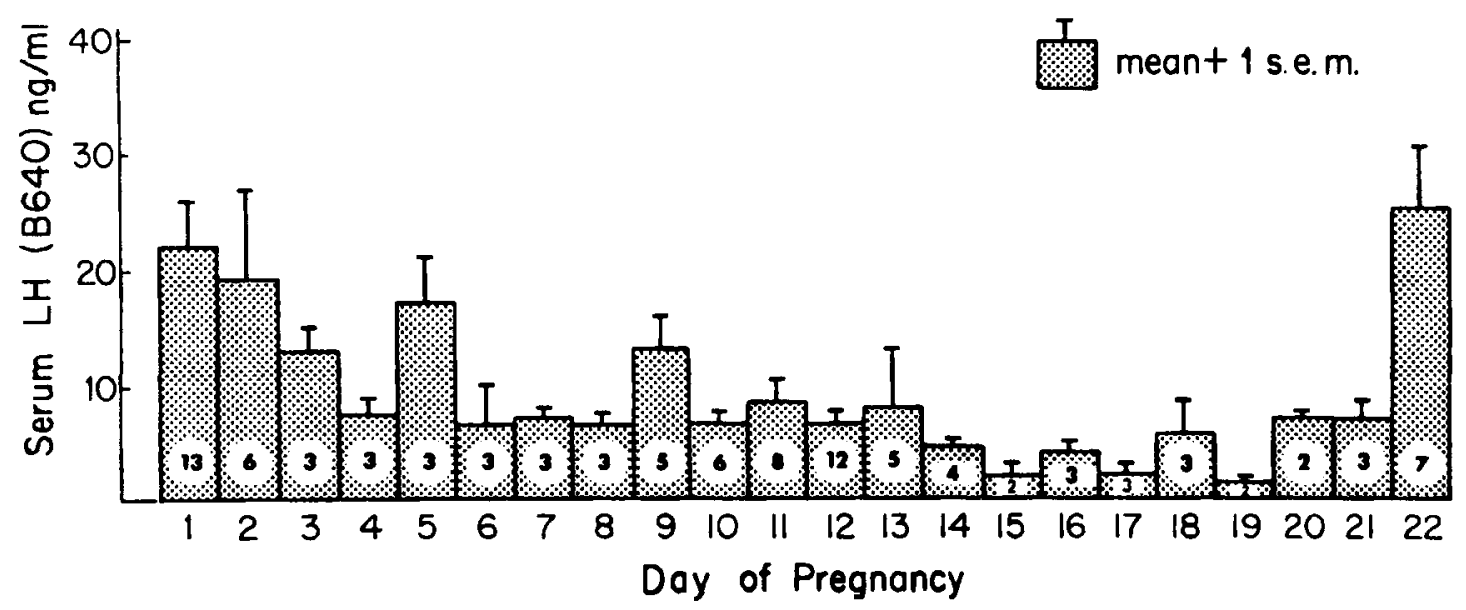

Fig. 7 Serum LH concentration at various times during pregnancy as determined by radioimmunoassay. B640 is the standard reference preparation. The number of rats used to obtain the specified mean concentration is given at the bottom of each bar.

During lactation, serum LH concentration (fig. 8) for the first seven days was equivalent to that on day 22 of pregnancy, but by day $9(33.6 \pm 9.6 \mathrm{ng} / \mathrm{ml})$ a rise in serum LH had occurred ( $p<0.01$ ). From days 11 to 21 of lactation serum LH was maintained at a somewhat lower concentration (average, $12.8 \pm 1.2 \mathrm{ng} / \mathrm{ml}$ ) $(\mathrm{p}<0.007)$.

Weight and hormone content of the pars distalis during pregnancy and lactation

During pregnancy and lactation, mini- mal variations were observed in the weight of the pituitary glands (pars distalis) either within the samples of a group studied at a specified time or between the mean values for groups obtained at different times (table 2). In addition, the mean weights of the glands for pregnancy (9.09 $\mathrm{mg})$ and lactation $(9.13 \mathrm{mg})$ were not significantly different. Hence, as would be expected the mean values calculated for the total glandular content of prolactin and LH varied with the time of gestation and lactation in a manner similar to the hormone concentrations.

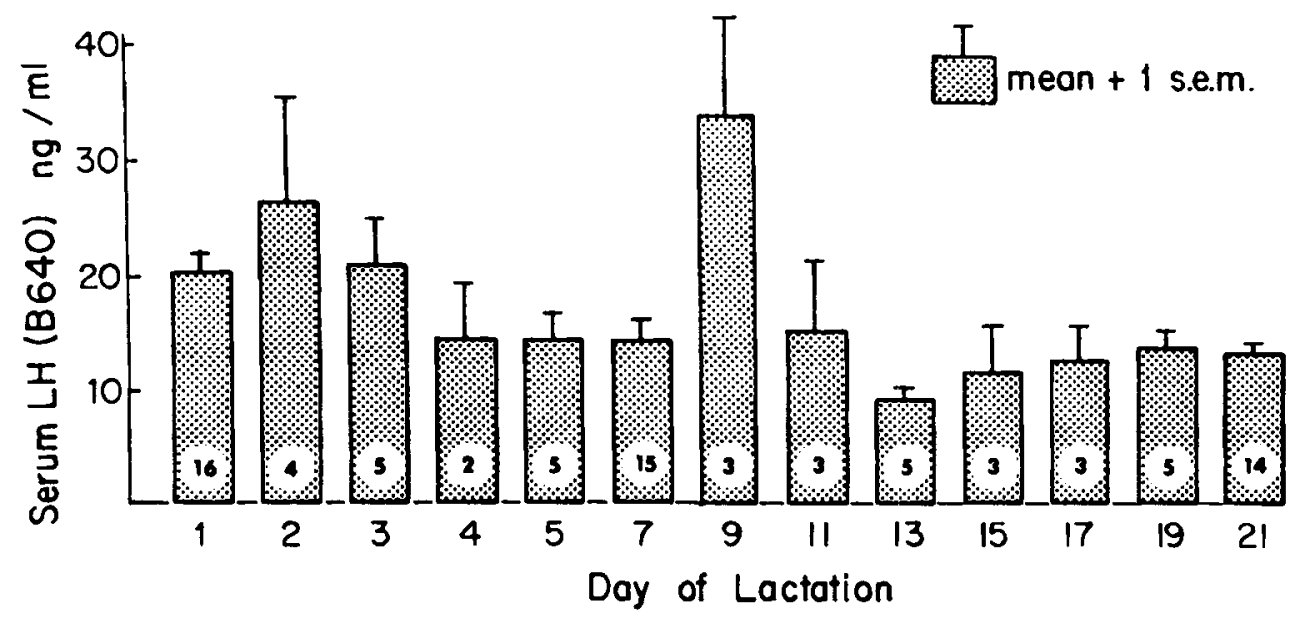

Fig. 8 Serum LH concentration at various times during lactation as determined by radioimmunoassay. B640 is the standard reference preparation. The number of rats used to obtain the specified mean concentration is given at the bottom of each bar. 
TABLE 2

Mean weight of the pars distalis at various times during pregnancy and lactation ${ }^{1}$

\begin{tabular}{cccc}
\hline $\begin{array}{c}\text { Day of } \\
\text { pregnancy }\end{array}$ & $\begin{array}{c}\text { Mean weight } \\
\text { of gland }\end{array}$ & $\begin{array}{c}\text { Day of } \\
\text { lactation }\end{array}$ & $\begin{array}{c}\text { Mean weight } \\
\text { of gland }\end{array}$ \\
\hline 1 & $9.2 \pm 0.3$ & 1 & mg \\
2 & $9.7 \pm 0.4$ & 2 & $8.9 \pm 0.3$ \\
3 & $9.5 \pm 0.7$ & 3 & $9.0 \pm 0.0$ \\
4 & $8.3 \pm 1.2$ & 4 & $9.3 \pm 0.3$ \\
5 & $9.7 \pm 0.3$ & 5 & $8.0 \pm 0.0$ \\
6 & $9.7 \pm 0.3$ & 7 & $8.7 \pm 0.2$ \\
7 & $9.0 \pm 0.5$ & 9 & $9.5 \pm 0.1$ \\
8 & $8.7 \pm 0.3$ & 11 & $9.3 \pm 0.3$ \\
9 & $8.7 \pm 0.3$ & 13 & $\mathbf{1 0 . 0} \pm 0.0$ \\
10 & $8.0 \pm 0.7$ & 15 & $\mathbf{8 . 3} \pm 0.8$ \\
11 & $8.8 \pm 0.3$ & 17 & $9.6 \pm 0.3$ \\
12 & $8.6 \pm 0.2$ & 19 & $9.3 \pm 0.6$ \\
13 & $9.3 \pm 0.6$ & 21 & $9.4 \pm 0.2$ \\
14 & $8.0 \pm 0.4$ & & \\
15 & $9.3 \pm 0.3$ & & \\
16 & $9.3 \pm 0.3$ & & \\
17 & $9.5 \pm 0.2$ & & \\
18 & $9.7 \pm 0.3$ & & \\
19 & $9.5 \pm 0.5$ & & \\
20 & $10.0 \pm 0.0$ & & \\
21 & $9.3 \pm 0.3$ & & \\
22 & $10.1 \pm 0.3$ & &
\end{tabular}

1 For the number of rats observed at each time see table 1.

2 Standard error of the mean.

\section{DISCUSSION}

In order to ascertain the functional significance of changes that occur in prolactin and LH-cells during pregnancy and lactation, it is first necessary to integrate the available evidence pertaining to secretory activity of these cells. The conclusions drawn from this survey will then be used to interpret the cytological alterations observed, considering first the prolactin cell and, secondly, the LH-cell.

\section{Pregnancy}

\section{Prolactin cells}

Prolactin levels in the hypophysis and serum. Earlier observations on pituitary prolactin concentration, based on bioassay of glands from the rat, are quite contradictory. Meites and Turner ('48) observed little change during gestation while Reece ('37) reported a slightly higher level at 21 days than at 12 days. In contrast, Grosvenor and Turner ('60) observed that early in pregnancy, pituitary prolactin concentration increased rapidly to a peak by day 16 and then declined during the last third of pregnancy. The latter fall agrees with more recent radioimmunossay data as obtained in my study and that of Bast and Melampy ('72). With respect to prolactin concentration in the serum, my findings are in general agreement with those of Amenomori et al. ('70), Linkie and Niswender ('72), Bast and Melampy ('72), Morishige et al. ('73) and Shiu et al. ('73). In all of these studies prolactin concentration was higher at the beginning and end of pregnancy than in the middle. Thus, based on both pituitary and serum concentrations of prolactin the synthesis and release of prolactin by the hypophysis continue at a high level during the first half of pregnancy, but are less active during the latter half except for the one or two days preceding parturition when they appear to accelerate.

During the first half of pregnancy prolactin cells $I$, which are the major prolactin cell form in both pregnant and nonpregnant rats, were unchanged from their condition in proestrus, in accord with minimal alteration in the concentration of pituitary prolactin. However, depressed secretion of prolactin during most of the latter half of pregnancy, was not sufficiently great to be reflected in a significant structural change in prolactin cells $I$.

For unknown reasons these observations 
differ from those of Lacour ('50) and Pasteels ('61) who, with histological staining, reported cytological evidence of prolactin cell activation during pregnancy. Thus, I did not observe a significant enlargement of prolactin cells $I$ as was reported by Lacour ('50, "orangeophils") and by Pasteels ('63, "erythrosinophils") to occur during pregnancy in the rat. Further, Lacour's ('50) orangeophil may not be identical to my prolactin cell I because she noted that the orangeophil is limited to the periphery of the gland. Apparently no attention has been given previously to the prolactin cell II; it also cannot be Lacour's orangeophil because it has a restricted laterocaudal distribution.

\section{Lactation}

Prolactin levels in the hypophysis and serum. During lactation as observed with radioimmunossay the only significant change in pituitary prolactin concentration was a fall from a peak on day 15 to a lower level on day 17. This observation differs from the results of Meites and Turner ('48) who found with bioassay that pituitary prolactin content increased significantly by days 3-7 and then declined. Grosvenor and Turner ('58) observed peaks at days 6 and 14 and a later fall.

Serum prolactin concentration in the postpartum rat of my study was higher during the first two days than at any other time during lactation. The concurrent high pituitary prolactin level indicates rapid secretion of prolactin at delivery. Midgley (unpublished) has shown that prolactin secretion is accelerated prior to the ovulation that occurs within hours after parturition; thus, the higher serum concentration of prolactin on the first two days of lactation, as observed in this study, may have reflected this postparturient surge.

In my study, since the mother rats were not suckled for 18 hours prior to death, the values for prolactin concentration were higher for the hypophysis and lower for the serum than those obtained by several other investigators who permitted nursing of the young (Meites and Turner, '48; Grosvenor and Turner, '58 and Amenomori and Nellor, '69). Also, with radioimmunoassy Amenomori et al. ('70) found that in rats which were permitted to nurse their young until death, serum prolactin was high for at least eight days, after which it declined to about half the level observed on day 1 of lactation. In addition, these workers noted that cessation of suckling for only three hours was sufficient to lower the serum prolactin level and increase pituitary prolactin content.

The available information does not permit broad generalizations regarding prolactin secretion during lactation, but an outpouring of prolactin after delivery of the young and a fall in prolactin toward the end of lactation seem to occur.

Correlation of pituitary prolactin conconcentration with prolactin cell cytology. During lactation, minimal change in the staining capacity, size, or number of prolactin cells I was evident when compared to the condition in late pregnancy. However, prolactin cells II lost most of their staining capacity early in lactation. These results are contrary to previously reported observations of several other workers. Thus, Everett and Baker ('45) reported a $100 \%$ increase in number of acidophils during the first three days of lactation and Pasteels ('61; '63) demonstrated that certain erythrosinophilic cells (presumptive prolactin cells) increase in size and number during early lactation. There may be several reasons for the discrepancies in these observations. Growth hormone cells (also a subgroup of acidophils) were included by Everett and Baker in their counts, since a method for accurate differentiation between prolactin and growth hormone cells was not available at that time. Therefore, their reported increase in number of acidophils three days after parturition may have been due, in part, to changes in growth hormone cells; the cytology of these cells during lactation has not been observed. Variation in results may have been influenced also by whether or not the newborn rats were nursed before termination of the experiment as well as by the length of this period. Thus, Pasteels ('63) demonstrated that suckling up to the time of killing the rat results in degranulation of prolactin cells in the mother's hypophysis and, in addition, prolactin content in the gland decreases (Reece, '37; Grosvenor and Turner, '60; Sar and Meites, '67). In my study degaanulation of prolactin cells 
was avoided by removal of the litter 18 hours before the mother rat was killed. This period of non-suckling was presumably sufficient to allow regranulation of the prolactin cells, since no apparent decrease in staining intensity or pituitary prolactin concentration occurred during lactation.

As for correlation with pituitary secretory activity, it is suggested that during early lactation prolactin cells II are stimulated to release their stored hormone, perhaps as a result of suckling stimulation or by a changing estrogen-progesterone ratio. They persist as lightly stained, rare cells throughout lactation. Their number may be too low for degranulation to be accompanied by a significant early fall in overall prolactin concentration of the gland, although such a decline is indicated. The later decline in pituitary prolactin concentration is not reflected by a significant change in prolactin cells $I$.

\section{Luteinizing hormone cells}

\section{Pregnancy}

LH levels in the hypophysis and serum. Pituitary LH concentration was extremely low the first four days following mating, but increased significantly during the remainder of pregnancy, reaching its peak around day 14 and declining slightly thereafter. These results are almost identical to the radioimmunoassay data of BrownGrant et al. ('72) and Bast and Melampy ('72). Similarly with bioassay Zeiner ('52) and Contopoulos and Simpson ('56) reported a two- to three-fold increase in pituitary LH potency, as compared with the level in nonpregnancy.

The curve for $\mathrm{LH}$ concentration in the serum was roughly the reciprocal of that for pituitary LH. Thus, serum LH concentration was higher during early and late pregnancy than in the middle. Similar results have also been observed by BrownGrant et al. ('72), Bast and Melampy ('72), Linkie and Niswender ('72), and Morishige et al. ('73). These reciprocal curves for serum and pituitary LH concentration indicate that luteinizing hormone is depleted from the pituitary gland and released into the blood in greater amounts during early and late pregnancy, but stored with little release during midpregnancy.
Correlation of pituitary LH secretory activity with LH-cell cytology. Basophils (presumptive LH-cells) have been reported to increase in number from early to late pregnancy in the guinea-pig (Weis, '35; Kirkman, '37), rabbit (Cameron et al., '66), bat (Herlant, '56), cat (Herlant and Racadot, '57), and rat (Wolfe and Cleveland, '33). The latter workers were unable to identify accurately the basophilic cell type that was involved in the rat. My study of the rat hypophysis, when stained immunohistochemically with anti-oLH, revealed that the $\mathrm{LH}$-cells are involved since they increase progressively in staining capacity, size, and number from early to late pregnancy. These changes are paralleled by a ten-fold increase in pituitary $\mathrm{LH}$ concentration from day 1 to day 14 of pregnancy. On the other hand, the fall in pituitary $\mathrm{LH}$ concentration during the latter half of pregnancy did not result in detectable morphological changes in the LH-cells. Thus, both cytological and physiological data affirm that $\mathbf{L H}$ is secreted early in pregnancy and that storage rather than secretion takes place for most of the remainder of pregnancy.

\section{Lactation}

$L H$ levels in the hypophysis and serum. Our data show that pituitary LH concentration was low at days 1 to 3 , rose to a maximum by day 13 , and maintained a somewhat lower concentration between days 15 and 21 . As during pregnancy there was an overall rough reciprocal relationship between pituitary and serum concentrations of $\mathrm{LH}$, secretion of LH being indicated soon after parturition with storage occurring as lactation progressed. Midgley (unpublished) measured pituitary LH concentration within hours after parturition and found that it fell from a high level to a nadir 18 hours later; the concentration obtained at this time was approximately equivalent to that which I observed on day 1 of lactation. In the same study, serum LH concentration increased sharply by five hours after parturition but declined thereafter so that by 18 hours the serum LH concentration approximated the level observed for serum LH at day 1 of lactation in my study.

It appears that at parturition the increas- 
ing estrogen levels, concurrently with the decreasing progesterone levels (Meites and Turner, '58; Fajer and Barraclough, '67; Shaikh, '71; Brown-Grant et al., '72; Sanyal and Villee, '73) trigger the release of LH from the hypophysis which causes postpartum ovulation in the rat. Therefore, the extremely low pituitary LH concentration and the high serum LH concentration which were observed during early lactation result from several hormonal interactions leading up to ovulation which occurs during the first day of lactation.

Correlation of pituitary LH secretory activity with LH-cell cytology. LH-cells underwent a drastic decrease in staining capacity and in number of identifiable cells on day 1 of lactation. This change was correlated with the postparturient outpouring of LH by the pituitary gland. As lactation progressed both the staining intensity and size of LH-cells, as well as the pituitary LH concentration, increased significantly. These findings for LH-cells agree with those of Everett and Baker ('45) who reported that the number of basophils was low early in lactation and gradually increased as lactation progressed. Observations in other species also support this conclusion. Kirkman ('37) and Cameron et al. ('66) found that the percentage of basophils drops following parturition in hypophyses of the guinea pig and cat, respectively; thereafter, the percentage was said to remain at approximately the level found in the nonpregnant state. Further, Cameron et al. ('66) postulated that this sharp decline in number of basophils was due to a loss of specific mucoid granules and was associated with the termination of pregnancy and the initiation of estrus. This observation is supported by investigations of Hill ('34) who reported that in the rabbit gonadotrophic content of the hypophysis declined prior to parturition and remained low throughout lactation. Thus, these changes in the cytology and secretory activity in LH-cells during pregnancy appear to characterize other mammals as well as the rat.

\section{LITERATURE CITED}

Amenomori, Y., C. L. Chen and J. Meites 1970 Serum prolactin levels in rats during different reproductive states. Endocrinology, 86: 506-510. Amenomori, Y., and J. E. Nellor 1969 Effect of suckling on serum prolactin levels in lactating rats. Fed. Proc., 28: 505 (abstract).

Baker, B. L., A. R. Midgley, Jr., B. E. Gersten and Y-Y. Yu 1969 Differentiation of growth hormone- and prolactin-containing acidophils with peroxidase-labeled antibody. Anat. Rec., 164: 163-172.

Baker, B. L., J. G. Pierce and J. S. Cornell 1972 The utility of antiserums to subunits of TSH and LH for immunochemical staining of the rat hypophysis. Am. J. Anat., 135: 251-268.

Bast, J. D., and R. M. Melampy 1972 Luteinizing hormone, prolactin and ovarian 20 a-hy. droxysteroid dehydrogenase levels during pregnancy and pseudopregnancy in the rat. Endocrinology, 91: 1499-1505.

Brown-Grant, K., C. S. Corker and F. Naftolin 1972 Plasma and pituitary luteinizing hormone concentrations and peripheral plasma oestradiol concentration during early pregnancy and after the administration of progestational steroids in the rat. J. Endocr., 53: 31-35.

Cameron, E., C. L. Foster and M. Allanson 1966 The mucoid cells of the adenohypophysis of the rabbit during pregnancy and lactation. J. Reprod. Fert., 12: 199-203.

Contopoulos, A. N., and M. E. Simpson 1956 Increased FSIH and ICSH content in the pituitary of pregnant rats. Anat. Rec., 124: 276277 (abstract).

Desclin, L. 1934 Contribution à l'étude expérimentale des rapports entre l'hypophyse et le tractus génital. Hypophyse de castration et hypophyse de grossesse. Arch. Biol., 45: 1-67.

Duddleson, W. G., A. R. Midgley, Jr. and G. D. Niswender 1972 Computer program sequence for analysis and summary of radioimmunoassay data. Computers Biomed. Res., 5: 205217.

Erdheim, J., and E. Stumme 1909 Ueber die Schwangerschaftsveränderung der Hypophyse. Beitr. path. Anat., 46: 1-132.

Everett, N. B., and B. L. Baker 1945 The distribution of cell types in the anterior hypophysis during late pregnancy and lactation. Endocrinology, 37: 83-88.

Fajer, A. B., and C. A. Barraclough 1967 Ovarian secretion of progesterone and 20 a-hydroxypregn-4-en-3-one during pseudopreg nancy and pregnancy in rats. Endocrinology, 81: $617-622$.

Fox, D., and K. Guire 1972 Documentation for MIDAS (Michigan Interactive Data Analysis System). The Statistical Res. Lab. of The University of Michigan.

Grosvenor, C. E., and C. W. Turner 1958 Pituitary lactogenic hormone concentration and milk secretion in lactating rats. Endocrinology, 63: $535-539$.

- 1960 Pituitary lactogenic hormone concentration during pregnancy in the rat. Endocrinology, 66: 96-99.

Haterius, H. O. 1932 The relation of pregnancy cells in the pituitary of the rat to the reproductive cycle. Anat. Rec., 54: 343-354.

Herlant, M. 1956 Correlations hypophyso-genitales chez la femelle de la chauve-souris Myotis myotis (Borkhausen). Arch. Biol., 67: 89-180. 
Herlant, M., and J. Racadot 1957 Le lobe antérieur de l'hypophyse de la chatte au cours de la gestation et de la lactation. Arch. Biol., 68: 217-248.

Hill, R. T. 1934 Variation in the activity of the rabbit hypophysis during the reproductive cycle. J. Physiol., 83: 129-136.

Kirkman, H. 1937 A cytological study of the anterior hypophysis of the guinea pig and a statistical analysis of its cell types. Am. J. Anat., 61: 233-287.

Lacour, F. 1950 Recherches sur la relation entre les cellules hypophysaires à granulations orangées (cellules $\epsilon$ de Romeis) et les phénomènes de lactation. $C$. R. Soc. Biol., 144: 248-249.

Linkie, D. M., and G. D. Niswender 1972 Serum levels of prolactin, luteinizing hormone, and follicle stimulating hormone during pregnancy in the rat. Endocrinology, 90:632-637.

Meites, J., and C. W. Turner 1948 Studies concerning the induction and maintenance of lactation. I. The mechanism controlling the initiation of lactation at parturition. Mo. Agr. Exp. Sta. Res. Bull., 415: 1-65.

Midgley, A. R. Jr., G. D. Niswender, V. L. Gay and L. E. Reichert, Jr. 1971 Use of antibodies for characterization of gonadotropins and steroids. Rec. Progr. Horm. Res., 27: 235301.

Morishige, W. K., G. J. Pepe and I. Rothchild 1973 Serum luteinizing hormone, prolactin and progesterone levels during pregnancy in the rat. Endocrinology, 92: 1527-1530.

Nakane, P. K., and G. B. Pierce, Jr. 1967 Enzyme-labeled antibodies for the light and electron microscopic localization of tissue antigens. J. Cell Biol., 33: 307-318.

Niswender, G. D., C. L. Chen, A. R. Midgley, Jr., J. Meites and S. Ellis 1969 Radioimmunoassay for rat prolactin. Proc. Soc. Exp. Biol. Med., 130: 793-797.

Niswender, G. D., A. R. Midgley, Jr., S. E. Monroe and L. E. Reichert, Jr. 1968 Radioimmunoassay for rat luteinizing hormone with antiovine LH serum and ovine LH-131I. Proc. Soc. Exp. Biol. Med., 128: 807-811.
Pasteel, J. L. 1961 Correspondance entre les granulations spécifiques des cellules hypophysaires de lactation et la prolactine. Ann. Endocr., 22: $822-825$.

- 1963 Recherches morphologiques et expérimentales sur la sécrétion de prolactine. Arch. Biol., 74: 439-553.

Reece, R. P. 1937 Lactogen and thyrotropic content of the anterior lobe of the pituitary gland. Mo. Agr. Exp. Sta. Res. Bull., 266: 1-104.

Sanyal, M. K., and C. A. Ville 1973 Production and physiologic effects of progesterone metabolites in pregnant and pseudopregnant rats. Endocrinology, 92: 83-93.

Sar, M., and J. Meites 1967 Changes in pituitary prolactin release and hypothalamic PIF content during the estrous cycle of rats. Proc. Soc. Exp. Biol. Med., 125: 1018-1021.

Severinghaus, A. E. 1939 Anterior hypophyseal cytology in relation to the reproductive hormones. In: Sex and Internal Secretions. Second ed. E. Allen, C. H. Danforth and E. A. Doisy, eds. The Williams and Wilkins Co., Baltimore, pp. 1045-1087.

Shaikh, A. A. 1971 Estrone and estradiol levels in the ovarian venous blood from rats during the estrous cycle and pregnancy. Biol. Reprod., 5: 297-307.

Shiu, R. P. C., P. A. Kelly and H. G. Friesen 1973 Radioreceptor assay for prolactin and other lactogenic hormones. Science, 180: 968971.

Stein, S. I. 1934 Experimental studies on the hypophysis cerebri. I. The effect of single pregnancy in the albino rat. Endocrinology, 17: 187-198.

Weis, M. 1935 Les modifications de la glande pituitaire du cobaye au moment de l'accouchement et après la mise-bas. Rev. Franc. Endocr., 13: $195-201$.

Wolfe, J. M., and R. Cleveland 1933 Pregnancy changes in the anterior hypophysis of the albino rat. Anat. Rec., 56: 33-45.

Zeiner, F. N. 1952 Pituitary gonadotropic fluctuation during pregnancy in the rat. Anat. Rec., 113: 255-267. 


\section{PLATE 1}

\section{EXPLANATION OF FIGURES}

All photographs on this plate are of sections stained immunohistochemically for prolactin cells. The sections were cut on a frontal plane. Figures 9,11 , and 13 represent one-half of a section through the hypophysis. $\times 31$. The areas illustrated at higher magnification (figs. 16, 18, 20) were located in the central region of the lateral lobe of the pars distalis. $\times 250$. D, pars distalis; I, pars intermedia; N, pars nervosa; $P_{1}$, prolactin cells $I ; P_{2}$, prolactin cells II.

9 Proestrous female. Prolactin cells are represented by the dark spots in the pars distalis. Prolactin cells $I$ are distributed uniformly in the pars distalis.

10 Proestrous female. Prolactin cells I are shown. They are of fairly uniform size.

11 Day 1 of pregnancy. There is little change in appearance of prolactin cells I when compared to those in the proestrous female (fig. 9). Prolactin cells II are not evident.

12 Day 1 of pregnancy. Prolactin cells I reveal little significant alteration when compared to those in the proestrous female hypophysis (fig. 10). Only a few weakly stained prolactin cells II can be seen (arrows).

13 Day 14 of pregnancy. At this magnification little change in prolactin cells is observed when compared to those on day 1 of pregnancy (fig. 11).

14 Day 14 of pregnancy. Prolactin cells I stain more intensely that at day 1 of pregnancy (fig. 12). Prolactin cells II are more numerous and also show increasing staining capacity (arrows). Inset: typical prolactin cell I and prolactin cell II in this section. $\times 1000$. 

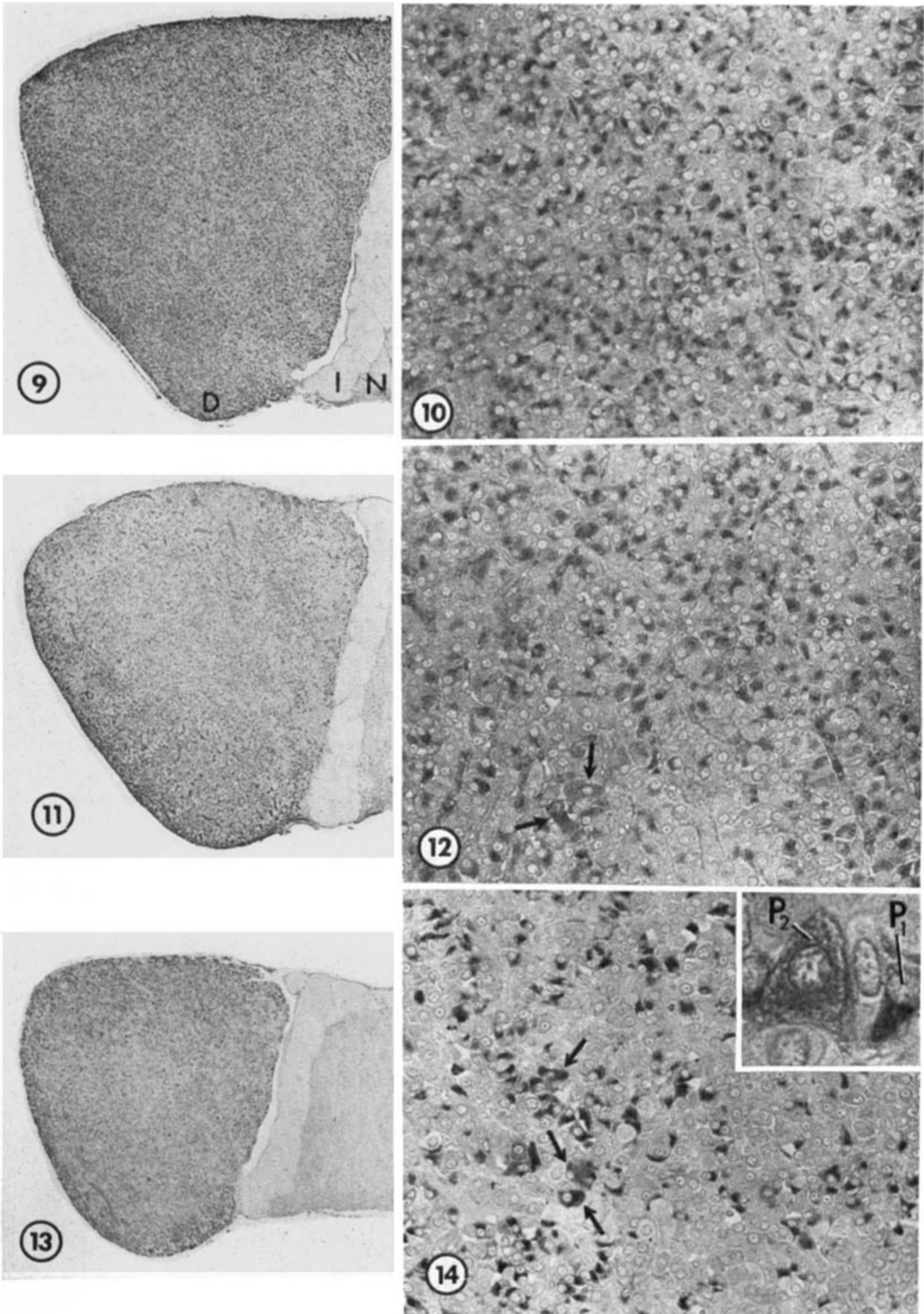
PLATE 2

EXPLANATION OF FIGURES

All photographs are of preparations stained for prolactin cells. The sections were cut on a frontal plane. Figures 15,17 , and 19 represent one-half of a section through the hypophysis. $\times 31$. The areas jllustrated at higher magnification (figs. 16, 18, 20) were located in the central region of the lateral lobe of the pars distalis. $\times 250$.

15 Day 22 of pregnancy. Prolactin cells I appear the same as on day 14 of pregnancy (fig. 13). Prolactin cells II are visible in the central and lateral areas of the pars distalis (arrows).

16 Day 22 of pregnancy. The staining capacity of prolactin cells I is not altered over that at 14 days (fig. 14), but prolactin cells II are stained more intensely (arrows). Inset: a typical prolactin cell II in this section. $\times 1000$.

17 Day 1 of lactation. Prolactin cells $I$ show little change in staining intensity when compared to those on day 22 of pregnancy (fig "15). Prolactin cells II are rare.

18 Day 1 of lactation. Prolactin cells I appear unchanged when compared to day 22 of pregnancy (fig. 16). However, prolactin cells II are fewer (arrow).

19 Day 21 of lactation. No change is apparent in prolactin cells $I$ when compared to day 1 of lactation (fig. 17). Prolactin cells II are not visible.

20 Day 21 of lactation. Prolactin cells I appear the same as for day 1 of lactation (fig. 18). Prolactin cells II are not evident in this field. 

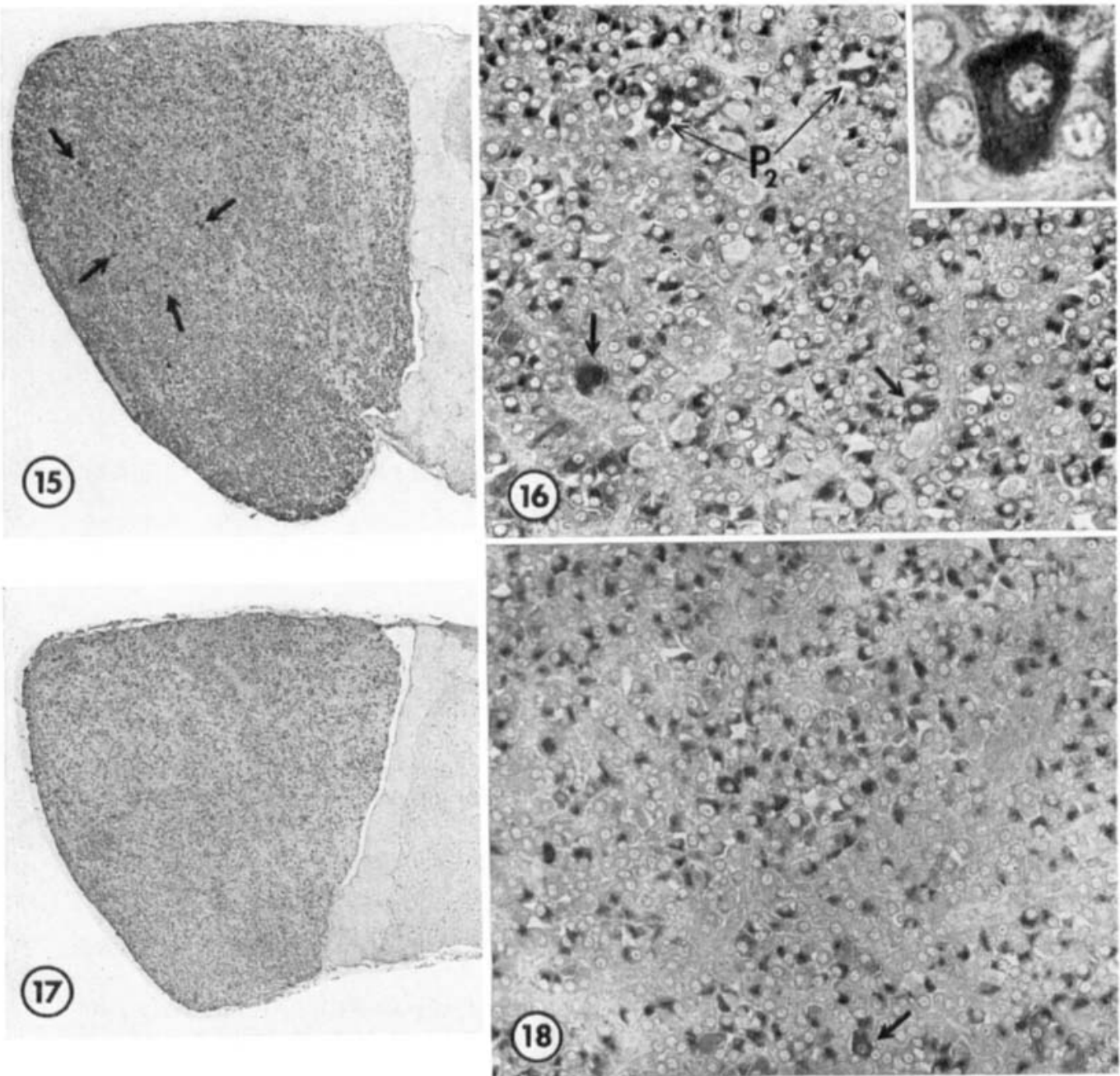

(17)
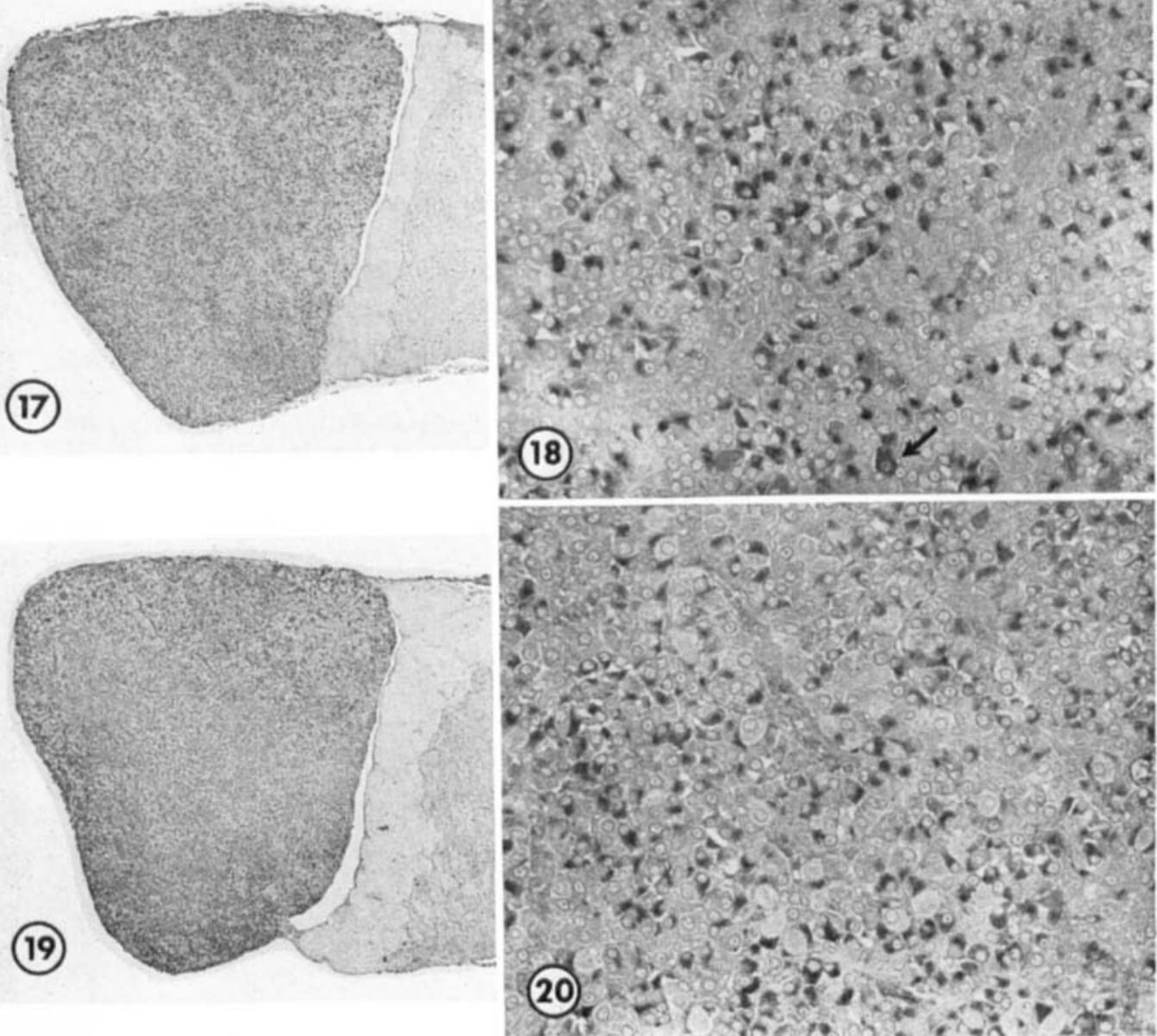


\section{PLATE 3}

EXPLANATION OF FIGURES

All photographs are of preparations stained immunohistochemically for LH-cells. The sections were cut on a frontal plane. Figures 21, 23, and 25 represent one-half of a section through the hypophysis. $\times 31$. The areas illustrated at higher magnification (figs. 22, 24, 26) were located in the central region of the lateral lobe of the pars distalis. $\times 250$.

21 Proestrous female. LH-cells are represented by the dark spots in the pars distalis. Note the staining intensity and number of identifiable cells.

22 Proestrous female. LH-cells are generally ovoid with some being polyhedral. Staining intensity is quite uniform among LH-cells. Inset: a typical LH-cell from this section. $\times 1000$.

23 Day 1 of pregnancy. There is a significant reduction in number of identifiable LH-cells, and in their staining capacity throughout the pars distalis as compared to those in the proestrous female hypophysis (fig. 21).

24 Day 1 of pregnancy. LH-cells are small, lightly stained, and apparently fewer when compared to LH-cells prior to mating (fig. 22). Inset: a typical LH-cell from this section. $\times 1000$.

25 Day 12 of pregnancy. LH-cells have increased in staining intensity as compared with their condition on Day 1 of pregnancy.

26 Day 12 of pregnancy. LH-cells reveal a significant increase in staining capacity and number when contrasted to LH-cells on day 1 of pregnancy. Inset: a typical LH-cell from this section. $\times 1000$. 

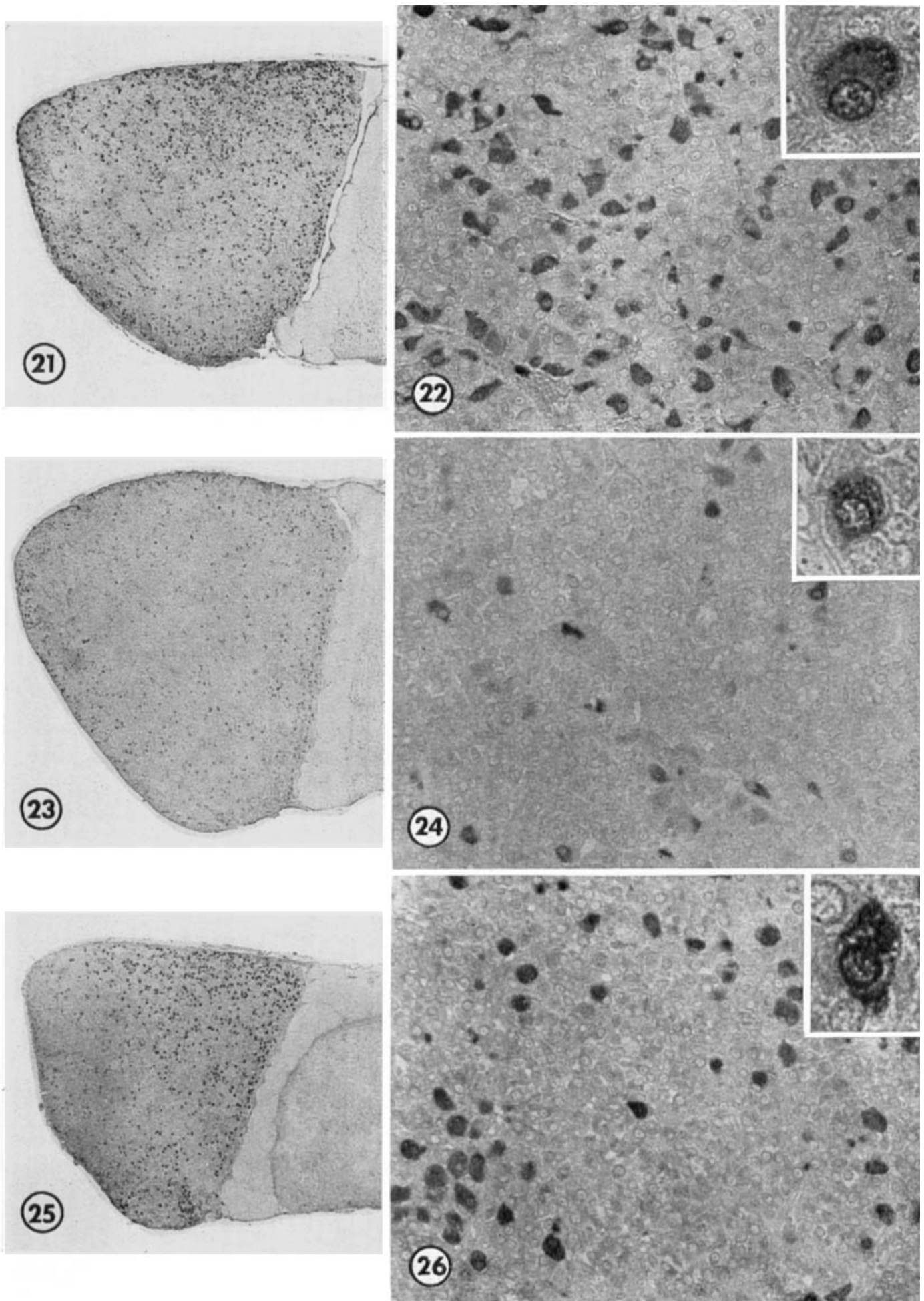


\section{PLATE 4}

EXPLANATION OF FIGURES

All photographs are of preparations for LH-cells. They were sectioned on a frontal plane. Figures 27, 29, and 31 represent one-half of a section through the hypophysis. $\times 31$. The areas illustrated at higher magnification were located in the central region of the lateral lobe of the pars distalis. $\times 250$.

27 Day 22 of pregnancy. The distribution of LH-cells is illustrated.

28 Day 22 of pregnancy. Note the increased intensity of staining, size, and number of LH-cells as compared to day 12 of pregnancy (fig. 26). $\times 250$. Inset: a typical LH-cell from this section. $\times 1000$.

29 Day 1 of lactation. LH-cells are less numerous than in late pregnancy (fig. 27).

30 Day 1 of lactation. LH-cells are small, lightly stained, and decreased in number after parturition. Compare with day 22 of pregnancy (fig. 28). Inset: a typical LH-cell from this section. $\times 1000$.

31 Day 21 of lactation. LH-cells are more numerous than on day 1 of lactation (fig. 29).

32 Day 21 of lactation. LH-cells are increased in staining capacity, size, and number over day 1 of lactation (fig. 30). Inset: a typical LH-cell from this section. $\times 1000$. 

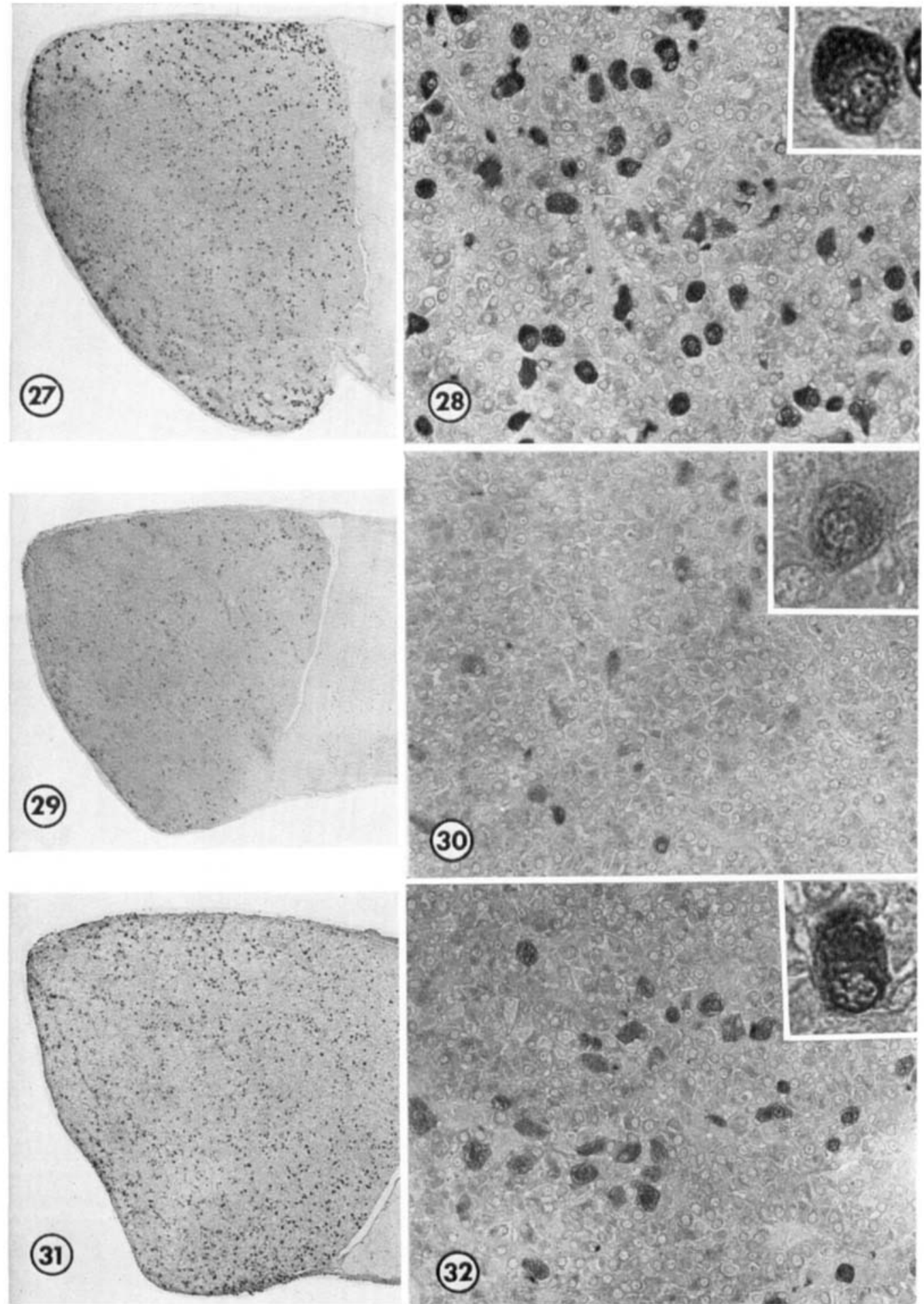